\title{
THE ROLE OF WOMEN IN THE MEXICAN CRISTERO REBELLION: LAS SEÑORAS Y LAS RELIGIOSAS
}

\begin{abstract}
$\mathbf{P}$ ARTICIPATION of women in the Cristero rebellion, the Catholic uprising against the anti-clerical revolutionary government of Mexico, has largely been ignored by historians. A fresh reading of the documents, and more important, conversations with the principal women in the movement, reveal that the traditional role of women in the church gave way to changed behavior in the 1920s. Not only were Catholic women of a traditionally oriented society capable of assuming leadership in a violent enterprise, but they were equally capable of falling back into their conservative patterns once the crisis had ended. Nevertheless, the vital role women played in the church-state conflict prepared them for the emerging role of women in the twentieth century.
\end{abstract}

The anti-clerical sentiment of Carranza's government peaked in 1917 with the promulgation of the new constitution. While nothing substantially new was added to the Laws of Reform of the 1857 constitution, they were reiterated with such a profusion of detail as to make the earlier charter seem mild in comparison.' Speaking out against the constitution, Bishop Pascual Díaz stated that Article 130 denied the juridical personality of the church and gave the government power to intervene in matters of worship and external discipline. Furthermore, Mexican citizens who became clergymen lost legal existence as citizens. ${ }^{2}$

Catholics in general, however, resigned themselves to the necessity of living with the constitution of 1917. As long as Presidents Alvaro Obregón

\footnotetext{
' Ernest Galarza, The Roman Catholic Church As a Factor in the Political and Social History of Mexico (Sacramento, 1928), p. 147.

${ }^{2}$ Pascual Díaz, Bishop of Tabasco, "State Vs. Church in Mexico," North American Review 225 (1928): $403-404$.
} 
(1920-1924) and Plutarco Elías Calles (1924-1928) made no attempt to enforce the laws, a shaky peace endured between church and state. By 1920 , then, the first phase of the revolution was over and the country enjoyed relative peace. Catholic social action was renewed but the emphasis had changed. Now Catholics were fighting for freedom of religion and education and against the secularism and socialism of the revolution. During this period Anacleto González Flores, a prominent Catholic in Jalisco, became a major spokesman for Catholic activism. He realized that an organization was needed to rally all Catholics to the cause of religious freedom. His answer was the Unión Popular, which he founded in the early 1920s. Hoping to unite all Catholics and to educate the masses on the need for Catholic social action, the UP was opened to all Catholics of Jalisco, regardless of age or class. ${ }^{3}$

González Flores was aware of the great dormant resource of Mexico, its women. Women, therefore, became a very important part of UP from its earliest days. Carmen Macías, who later became a leading general in the Brigadas Femeninas, worked closely with him and speaks of the time in 1926 when Anacleto sent her and several other women to Mexico to deliver a letter to President Calles asking him to end the persecution of the Church. The letter was delivered, but the President refused to see them or any other Catholics. When she asked about the letter, she was told that all letters and petitions that the President received were good for the wastebasket. The angry women returned to Anacleto. When he was told of the reception they had received, he said, "This affair has no remedy. To arms!" ${ }^{4}$

Throughout Mexico women began to answer the call of the church to become more involved in social action. In 1920 the Unión de Damas Católicas de Mexico (Damas) was organized and began publishing $\mathrm{La}$ Dama Católica in an effort to reach more women. The editor of the paper claimed that women were not "feminists in the exaggerated sense of the word." ${ }^{5}$ Women's place was still in the home, but feminine influence in social not political matters would be a great help. ${ }^{6}$

In 1922 the Damas held their first national congress in an effort to mobilize the influence of Catholic women within the family for the

\footnotetext{
${ }^{3}$ David Bailey, Viva Cristo Rey! The Cristero Rebellion and the Church-State Conflict in Mexico (Austin: University of Texas Press, 1974), p. 42.

${ }^{4}$ Interview with Carmen Macías, March 7, 1979.

${ }^{5}$ La Dama Católica, September 1, 1920.

${ }^{6} \mathrm{Ibid}$.
} 
Christian restoration. Its activities were strictly social and religious, not political. The Damas worked closely with the Asociación Católica de la Juventud Mexicana and later cooperated with the Liga, which coordinated the war effort during the Cristero Rebellion.?

The organization grew rapidly and by 1925 boasted a membership of eight hundred in the city of Guadalajara. The Damas performed a variety of works. They visited hospitals, orphanages, and prisons, and distributed clothes to the poor. In addition, they founded La Liga de Señoritas Empleadas de Comercio y Oficina, whose activities included finding work for women in need and sponsoring fiestas to provide fresh air and exercise for factory women. The Damas also found normal schools for women. Between 1922 and 1924 these schools graduated 95 women who then began their careers as Christian educators. Ten catechetical centers were set up in the city to provide religious instructions for the young. Promoting the works of the Damas was an active and articulate press, $L a$ Mujer Católica Jaliscense. ${ }^{8}$

In October of 1920 the bishops created a Mexican Social Secretariat under Alfredo Méndez Medina. Father Medina, a Jesuit sociologist, conducted conferences thorughout Mexico, organizing working men, and spreading the teachings of the church on social action. ${ }^{9}$ Realizing the need for similar groups for women, Father Medina approached Sofia del Valle in 1922 to discuss this matter. Under his guidance, Sofia organized small groups of factory and office workers, meeting with these women in the evenings for cultural and religious training. ${ }^{10}$

Although women became more involved in social action and community affairs, the church remained clear on its stance on their role in society. In 1919 the Semana Social, a Catholic workers' organization, publicly condemned Feminism as irreligious. " While the church recognized the source of strength it possessed in its women and the important role they would play in its social action programs, it felt that women's place was still in the home, where they were to instill Christian principles in their children. They might move out into the community and

\footnotetext{
${ }^{7}$ Alicia Olivera Sedano, Aspectos del conflicto religioso (Mexico: Instituto Nacional de Anthropologia E Historia, 1966), p. 88.

${ }^{8}$ La Dama Católica, January 1, 1925.

${ }^{9}$ Antonio Rius Facius, La juventud católica la revolucion mexicana (Mexico: Editorial Jus, 1963), p. 242.

${ }^{10}$ Interview with Sofia del Valle, January 12, 1979.

${ }^{11}$ Robert E. Quirk, "The Mexican Revolution and the Catholic Church, 1910-1929," Ph.D. dissertation, Harvard University, 1950.
} 
become involved in social welfare and religious activities, but politics were not part of their realm.

In February of 1926 a genuine church-state crisis erupted at the national level. Its immediate cause was the publication of an interview with Archbishop José Mora del Río in the February 4 edition of El Universal. According to correspondent Ignacio Monroy, the archbishop made the following statement: "The Episcopate, clergy, and Catholics do not recognize and will combat Articles 3, 5, 27, and 130 of the present Constitution." Reacting immediately, the government called for an investigation. Copies of the archbishop's protest of 1917 were distributed on the streets of Mexico City on February 7 by a Catholic group, only adding fuel to the fire. On February 11 the archbishop issued a statement to the paper saying that he was misquoted. Following the government investigation, all charges against the archbishop were dismissed and Monroy was fired because of inaccuracy in reporting. ${ }^{12}$ Nevertheless, the damage was done, and the incident would have far-reaching consequences.

Under the pretext of retaliating against the archbishop's provocation, the government unleashed a severe attack. School closings were ordered throughout the Republic. In Coyoacán, the Visitation School was closed because religion was being taught, and the girls were forced out into the streets, some going to the United States Embassy and others to private homes. All day visitors came to the school. They included well-known women of high social status, renowned men in banking, commerce and the professions, and humble women in rebozos (peasant shawls). The show of concern proved fruitless, however, and the visitors shortly withdrew, realizing they could accomplish nothing. ${ }^{13}$ Another school, Colegio de Jesús María, continued operating after the religious who ran the school fled. A distinguished lady, Doña Amada Díaz de la Torre, became its new director. Ironically two nieces of the anti-clerical government's minister Adalberto Tejada attended this school. ${ }^{14}$

In Guadalajara an Italian college was closed and students were forced to find housing. Even the chapel, customarily used by local residents, was closed. A distinguished group of women sent a telegram to the secretary of government signed by one thousand mothers. It read: "We do not want to be treated as pariahs in our own country. While Masonic lodges, sectarian

\footnotetext{
${ }^{12}$ Bailey, Viva Cristo Rey!, pp. 62-64

${ }^{13}$ Excelsior, February 16, 1926

14 Ibid.
} 
schools, and foreign Protestants enjoy privileges, Catholic establishments are inhumanly closed. We ask for justice and equality before the law."15

Rallying to the cause, the Damas of Guadalajara protested the closing of the Visitation Academy in the following letter to Calles: "We have supported the closing of our schools and the parting of our teachers because we are women and we are not able to resist the persecution of the church, but neither are we able to remain silent before the consummate outrages and we protest them with all our souls, with all our ardor." 16 This was March of 1926. In a few months women whose protests went unanswered would physically resist government troops at the church doors.

Many petitions and letters were sent to state and national congresses, but they went unheard. When the "Ley Calles," providing that Article 130 of the constitution would be strictly enforced effective August 1, became public, the battle lines were drawn. ${ }^{17}$ In addition, only ministers who presented a certificate proving the law had been fulfilled could perform ceremonies. The bishops were left with little choice. Compliance on their part with the "Ley Calles" would constitute a complete victory for the government. A pastoral letter drawn up by the bishops made public on July 25 stated in part "... the decree of July 2 of this year attacks the rights of the church ... it would be criminal for us to tolerate such a condition. We command that after July 31 all worship requiring the services of priests be suspended." 18 Compromise was now out of the question as both sides prepared to fight to the end.

Leadership for the Catholic resistance movement was taken up by an organization founded March 9, 1925, the Liga Nacional Defensora de la

${ }^{15}$ El Pais, February 23, 1926.

${ }^{16}$ Serie Conflicto Religioso. Diversos archivos y fondos bibliográficos. Selección de impresos y manuscritos por Alicia Olivera Sedano, Instituto Nacional de Antropología e historia microfilmado, Castillo de Chapultepec, Mexico, D.F.

${ }^{17}$ Article 130 The following are sections of Article 130 which were most objectionable to the Church:

"Religious institutions known as churches have no juridical personality.

"Ministers may not vote, hold office, or assemble for political purposes.

"The state legislatures are to have the right to determine the maximum number of ministers in any locality. Only Mexicans by birth may be ministers of any religious creed.

"Permission to dedicate new temples must be received from the Department of the Interior ...."

Wilfrid Callcott, Liberalism in Mexico, 1857-1929 (Stanford: Stanford University Press, 1931), pp. 277-278.

${ }^{18}$ Galarza. The Roman Catholic Church, p. 158. 
Libertad Religiosa ( $L N D L R$ ). A civic organization open to all Mexican Catholics, women and young people as well as males, its aim was to work for the defense of religious liberty and to "uproot the Constitution of all its injustices." 19

On August 15 the first local uprising took place in Chalchihuites, Zacatecas. More uprisings followed in September and October in Guanajuato and Durango. Although the Liga had not initiated the armed conflict, its leaders offered to coordinate the war effort once it had begun. By January 1, 1927, the Liga had organized a general uprising, soon called the Cristero rebellion, and assumed leadership over it. The episcopate accepted the leadership of the directing committee of the Liga but did not become directly involved in the armed movement. The bishops promised the Liga not to condemn the movement and to inform Catholics that it was a legitimate armed defense against an unjust government. ${ }^{20}$ Catholics mobilized to form a resistance movement in which women were to play three distinct roles: Las señoras, middle and upper class married women of the cities, became passive protesters; Las religiosas, the persecuted women religious, went underground, providing sanctuaries for the Blessed Sacrament and places of worship; and Las jóvenes, young women, became active revolutionaries. ${ }^{21}$ This paper will explore the deportment of the first two groups, the passive resisters, while the exploits of las jovenes must be reserved for another study.

\section{Las Señoras: The Passive Protesters Support the Cristeros}

Las señoras mobilized their efforts through the Unión de Damas Católica (Damas), reorganized in 1922 under Father Méndez Medina. At their first national congress, the Damas had pledged to defend freedom of education even with their lives. Boasting of some of the most prominent members of society, they became the mouthpiece for Catholic women during the early years of persecution. ${ }^{22}$

In February of 1925 a permanent alliance, the Liga Social Católica (Liga) was formed by the four leading Catholic groups in Mexico, one of which was the Damas. The Liga attempted to coordinate and unify the

\footnotetext{
${ }^{19}$ Timothy Hanley, "Civilian Leadership of the Cristero Movement: The Liga Nacional Defensora de la Libertad Religiosa and the Church-State Conflict in Mexico, 1925-1938," Vol. 1 Ph.D. dissertation, Columbia University, 1977.

20 Jbid. pp. 87-90, 273.

${ }^{21}$ Interview with Padre Rafael Ramírez Torres, S. J., March 7, 1979.

22 Serie Conflicto Religioso, Rollo 43.
} 
action of each group without endangering its autonomy or initiative. Clara Arce, the Damas representative, sent circulars to all regions of the republic, explaining the work of the Liga. With few exceptions the response was overwhelmingly favorable. ${ }^{23}$

On March 20 Excélsior published the manifesto of the Liga, which stated in part: "We have been called to combat; we are obliged to go to it by unjust and tyrannical persecutions..." Onlberto Valenzuela, the secretary of government, immediately issued a statement declaring the manifesto seditious and in violation of Article 130 of the constitution, which prohibited formation of political groupings of a confessional nature. ${ }^{24}$ Much to the surprise of the Liga, the founder-president of the UDC, Señora Elena Lascuraín, responded to the manifesto with disapproval because of its political nature. She reminded the Damas that their role was purely religious. However, she called upon all persons belonging to the Unión to work with the Liga in its effort to recover religious liberties and to fight for the right to educate their children and those of the poor Mexican families according to the dictates of their Catholic consciences. ${ }^{25}$

The controversy over the Liga's political status continued throughout the year, while the government took a "wait-and-see" attitude. Meahwhile, the Damas actively promoted the Liga's program by collecting funds, spreading propaganda, and sending protests to the government. Protesting the expulsion of foreign priests in February of 1926, the Damas sent a letter to the President saying, "The Constitution guarantees the exercise of all cults, and we don't have enough [priests] to meet our needs. We have not violated the Constitution. We will work in harmony with the government." ${ }^{26}$ Three months later when the apostolic delegate, Msgr. Jorge Jose Caruana, was expelled, the Damas sent another protest, but once again it went unanswered. ${ }^{27}$

The first confrontation with government troops occurred at the Church of the Sacred Family in Colonia Roma, a wealthy section of Mexico City. Under the pretext that foreign priests were officiating there, the government ordered its closing. When the soldiers arrived at the church, members of the UDC and a group of Servants of St. Zita blocked the

\footnotetext{
23 Ibid.

24 Excelsior, March 25, 1925.

25 Ibid.

${ }^{26}$ El Universal, February 14; 1926.

${ }^{27}$ Excelsior, May 18, 1926.
} 
entrance. Refusing to leave at the soldiers' command, the women were attacked with waterhoses. Not to be denied, they rose from the ground and advanced upon the soldiers with rocks. The cavalry was brought in and charged the women until they finally dispersed. One hour later a feminine army of five thousand marched to the palace of the secretary of the governor, asking to meet the minister, Colonel Tejada. Their request was denied and the cruel scene was reenacted. Joining his soldiers, Police Inspector General Roberto Cruz lashed out with his whip at some of the most prominent women of Mexico. ${ }^{28}$

Mexico was shocked at the show of brute force against the women at Sacred Family Church. By the example of their moral force and courage in resisting oppression, they evoked widespread admiration. On the basis of this incident, they issued the following appeal: "Men of the whole Republic, there are your models. Go hide your shame in the dark caverns of our forests." 29

On July 3 Catholic Mexico received the distressing announcement of the "Ley Calles." The response was immediate. The Knights of Columbus cried out against its injustice and the ACJM declared they were prepared to fight. The Damas, more cautious, stated: "We will be unconditionally with the prelates whatever circumstances prevail." ${ }^{30}$ Siding with the bishops meant the Damas would necessarily take a more passive role in the uprising to follow.

A few weeks later three of the most prominent members of society, Sra. Concepción Lascurain, Sra. Refugio Goribar de Cortina, and Sra. Juana Pimental de Labat were detained by the chief of police, simply because they promised to carry out the social program of the Liga. ${ }^{31}$

After the bishos proclaimed the cessation of religious services and their' support of the boycott, the Damas became actively involved in the protest against the government. Promoting the boycott, the Damas of Guadalajara boldly printed propaganda in an office right below Gov. Luna Gonzalez's balcony. ${ }^{32}$ Also, without his knowledge, Gonzalez's wife was providing places of refuge for hunted priests. Through the popular support of the city's Catholics, both activities were carried on successfully without government detection. ${ }^{33}$

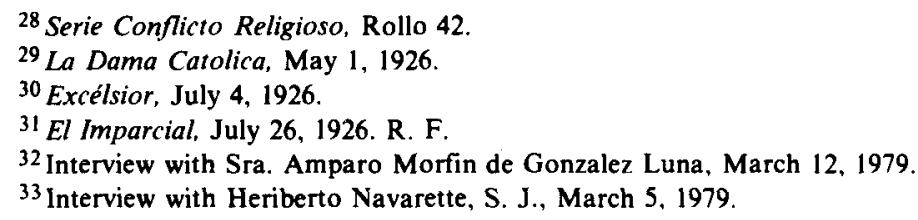


On one occasion two women were passing out propaganda in the Plaza of San Miguel Allende, Guanajuato, when the chief of military operations apprehended them. Refusing to give the propaganda to the police, they were taken to headquarters and threatened with rape by the soldiers. One thousand men gathered outside the headquarters with guns in their serapes, and a commission of Damas requested their release. The crowd shouted, "Death to the government and to Calles!" Fearing for their lives, the soldiers had no other choice but to release the women. ${ }^{34}$

A similar incident occurred in front of the Doblado Theater where a group of Catholic women of ACJM tried to convince people to boycott the afternoon performance. When not a single person purchased a ticket, the municipal president seized the leader of the women, Salvador Vargas. The women were then escorted to the inspector of police, with the crowd following close behind. After reprimanding the women, the inspector ordered them to return to their homes. Vargas, however, was detained, and the hostile crowd, crying for his release, threatened to free him by force. Realizing the gravity of the situation, the inspector released Vargas as the crowd responded with cries of "¿Viva Cristo Rey!" 35 As Catholic resistance grew, similar incidents would be repeated all over the republic.

In a letter to her cousin, Carmen Torres Quesada describes her town, Arandas, during the first months after religious services had ended. "Two and a half months without the cult [sacraments] seems like a century. Doors and windows show mourning. All places of diversion are closed. All is sadness and bad humor. Women, young and old, wear black. Calles calls the boycott ridiculous. Although our tabernacle is cold, the temple has more people than before, but even if we stay there all day we remain empty. Mexico seems like a sepulchre." 36

Responding to Catholic complaints, the bishops called off the boycott in October. During the next two months the Damas continued spreading propaganda against the government's persecution and organized processions across the country in honor of Christ the King. However, as the scattered uprisings turned into all-out war against the government, the Damas limited their activities to the collection of funds for war captives and the unemployed. Even though the UDC did not become directly involved in the war, many of its members raised money to free prisoners,

\footnotetext{
34 Private Archives of Antonio Rius Facius, dated August 13, 1926.

35 Joaquin Cardosa, S. J., Los mártires mexicanos (Mexico: Buena Prensa, 1953), pp. 84, 85.

${ }^{36}$ A letter from Carmen Torres Quesada to her cousin, Rafael Ramirez, S. J., October 12, 1926.
} 
supplied them with meals, and provided moral strength and encouragement to those on the battle lines. Some of these women opened their homes to the wounded and took in families whose fathers had been killed in the war. ${ }^{37}$ Doña Luz Noriega de Reguer's house was an asylum for Cristeros during the war and a center of propaganda and local meetings. She and her daughter organized and carried out local "civic journeys" of the Liga and helped distribute propaganda. ${ }^{38}$ Risking arrest and imprisonment, many women provided shelter for renegade priests and places for them to minister to the people. Sra. Elena Lascurain opened her house to the Cristeros. Heriberto Navarrete spent thirty days there, being well treated by her whole family. Srta. Arce and Sra. Pitman de Labarthe, both active Damas, also opened their homes to the soldiers, ${ }^{39}$ and Sra. Amparo Morfín concealed 14 Jesuits in her home in Guadalajara during the rebellion. Father Julio Dávila and a world-renowned French mathematician-priest, the first priests to seek refuge in her home, were rescued by her husband when the school in which they taught was under fire by the government. Though Morfin housed at least two priests at a time throughout the war, she was never bothered by the police. Her home functioned as a parish, where religious gathered for mass and people of every class came from great distances for marriages and funerals. ${ }^{40}$

The UDC provided leadership for women during the early years of persecution, but when the rebellion became an organized war against the government in 1927, the Damas disassociated themselves from it because of its political implications. Still, las señoras continued to assist the war effort independently of the UDC, distributing propaganda, providing places of worship and housing for hunted priests, and, most importantly, inspiring men to fight for the cause of the church. "What would the Mexican men be if the Mexican Catholic women did not exist?" asked José Pedro Duran at a special gathering in honor of the great Cristero leader, Miguel Palomar y Vizcarra. "Dolores Silva Palomar has been the sustenance of Miguel." 41

\footnotetext{
${ }^{37}$ Selections from Antonio Pompa y Pompa on microfilm, Guadalajara Series, Rollo 108, September 25, 1927.

38 David. Tomo IV, August 1958-July 1960, p. 154.

${ }^{39}$ Heriberto Navarrete, Por Dios y Por la Patria (Mexico: Editorial Jus, 1964), p. 136.

40 Interview with Señora Amparo Morfin. March 12, 1979.

${ }^{41}$ David, Tomo VII, November 1964, p. 66.
} 


\section{Las Religiosas: The Persecuted Women Strike Back}

Las religiosas of Mexico played a role similar to that of las señoras in that they did not become directly involved in the war. As the object of government persecution, however, they were forced to go underground, where they rendered valiant service to the religious cause.

In February of 1926 government officials began closing Catholic schools, especially those run by foreign religious. Among the first to feel the blow was Madre Sample, a North American sister who was forced to evacuate Visitation School in Mexico City. Carrying mattresses, bookcases, and desks into the streets, students emptied the building before the government takeover. In a few days forty-nine schools closed, and within a month 157 were evacuated in the Federal District alone. ${ }^{42}$ As women religious were encouraged to leave the country, parents of children in their schools counseled peaceful compliance to avoid greater harm. The sisters, however, were not willing to submit passively. One hundred fifty of them met with the archbishop of Morelia to discuss the government's anticlerical laws. As a result of the meeting the religious published a manifesto to their pastors declaring "All religious are disposed to enter a difficult religious fight... in order to reform the articles of the Constitution." 43 The sisters stated, however, that they would abide by the wishes of their bishops if they disagreed with this stand. If the bishops were in agreement, the religious would close their schools until victory or death and would continue living a community life in modest homes. The episcopate approved of the manifesto, and Archbishop Orozco Jiménez lauded these courageous women who preferred death to submission. ${ }^{44}$

A woman religious from Guadalajara, "Madre Anna," reminisced about her experiences during the first months of persecution. ${ }^{45}$ As a young teaching religious in Mexico, she first became aware of the seriousness of the problem one day in February when her superior called the sisters together to inform them of recent events. "We took off our habits," Madre Anna related, "and the only clothes we had were those used for the theater, which were terrible! Sometimes we laughed about it." Because of the danger, the bishops had told them to finish school quickly and leave the country. In several instances religious had been raped by the soldiers.

\footnotetext{
42 Nicolás Marín Negueruella, La verdad sobre Méjico (Santiago, Chile, 1928), p. 166.

43 lbid., p. 162.

44 Ibid., pp. 162-164.

45 "Madre Anna" requested that her name be withheld to protect her community, which is active in Mexico today.
} 
In July she and her community of forty left for Laredo, Texas, where they found asylum. After teaching Mexican children in Texas and Louisiana for the next few years, they returned to Mexico in 1931. Their difficulties were not yet over, for during the next few years the government intensified its attacks upon the Church, and the religious lived under perilous conditions. Madre Anna concluded, "We were young, but we suffered for Christ enthusiastically. I am happy to have suffered in that time." 46

Shortly after the "Ley Calles" had been passed, Sor Maria Esperanza of the Congregation of Jesus sent a letter to the President appealing on behalf of all exclaustrated nuns. "We want to die in our cloisters," she declared. Recalling the good works of the nuns in schools, hospitals, and homes for the elderly, she appealed to Calles to end his attack upon religious and implored him not to throw God out of the schools. ${ }^{47}$ This petition, like so many others before it, was ignored.

Some communities were ordered by their superiors in Rome to leave the country. Since the majority of these sisters were young and were just beginning their education, they would have been of little help to the church by remaining in Mexico. Quite a few sisters went to Spain, some to other European countries, and a few to the United States. Because of the Depression, the North American prelates did not encourage the sisters to emigrate. Since the nuns spoke no English, they would be unable to teach catechism, and the bishops feared they would be an added burden on the church. 48

Since living together in communities invited great danger, most religious who remained in Mexico sought refuge among families and friends. Living as in the days of the catacombs, they rose during the night to pray for the end of religious persecution. By day they hid the Blessed Sacrament between crockery and dishes or behind books on the shelves.

Women religious generally fled to small towns, where they enjoyed the protection of the Cristeros and could be of service to them. "Their greatest apostolate," said Father Ramirez, "was to sustain the spirit of the soldiers." 49 When the Cristeros passed through the towns, the sisters

\footnotetext{
${ }^{46}$ Interview with Madre Anna of Guadalajara, March, 1979.

${ }^{47}$ Serie Conflicto Religioso, Rollo 42, Judith, October, 1926. An organ of the Damas of Orizaba, Veracruz.

${ }^{48}$ Interview with Madre María de la Luz, Sister of Jesus and Mary, February 6, 1979.

${ }^{49}$ Interview with Rafael Ramírez, S. J. March 7, 1979.
} 
provided them with food, clothing and shelter. In an effort to sustain the soldiers' spiritual strength, they provided for Masses and religious devotions. On one occasion the commander-in-chief of the Cristero army, Enrique Gorostieta, met several religious fleeing from San Miguel. As soon as the sisters realized that the soldiers were Cristeros, they returned to the town and prepared a meal for them. Inspired to do more for the cause, they offered to take up arms beside the soldiers. Gorostieta remarked, "Even in pious, inoffensive nuns is revealed the spirit of war." 50

The religious performed another essential task through a wellorganized spy system. By way of mail, telegraph, or direct contact, the sisters informed the Cristeros of federal movements within the towns. They were able to warn soldiers staying with families to flee before a search was carried out. ${ }^{51}$ Working behind the scenes, these religious aided the cause of their brothers-in-arms.

Through the Brigadas Femeninas, individual religious became directly involved in war activity. A majority of them belonged to the nursing division and worked in hospitals located in caves in the mountains. In Las Villas de Velásquez a group of sisters procured the necessary surgical equipment and actually performed operations. They had to move about frequently to avoid government troops and hostile agraristas (the beneficiaries of agrarian reform who generally fought for the government), but they were never discovered. ${ }^{52}$

Madre María del Carmen Gutiérrez, a Sister of Charity, belonged to the Brigadas Sanitarias of Los Altos, a division of the Brigadas Femeninas. Twice she and her companions were surprised while they cared for their patients in the hills near San Miguel. The first time Madre Maria safely hid the wounded from the federal troops. During the second attack she was not so fortunate and had to flee as soldiers killed all her patients. Arriving at the town of San José de la Presa, Madre María began teaching Christian doctrine to the young children. One day when they were having a fiesta for the first communion class, the federal soldiers attacked the town. Escaping once again to the hills, she resumed her work caring for the wounded. Soon agraristas attacked once again and she was forced to leave the country in July of 1929. After the arreglos (church-state settlement) she returned to Guadalajara and continued her nursing work. ${ }^{53}$

\footnotetext{
50 J. J. González, Los Cristeros (México, 1930), p. 71.

51 Interview with Rafael Ramírez, S. J.

52 Impacto, June 15, 1977, p. 33.

${ }^{53}$ Serie Conflicto Religioso, Rollo 26.
} 
Petra Muñoz and Vicenta García, Sisters of Charity, cared for the wounded in the hills of Leguna. Constantly harassed by agraristas, they moved from place to place. Because of ever-present danger, they were unable even to build a fire and had to live on a diet of maize and a little wheat. Lacking water, they drank animal urine and the liquid from leaves of uncultivated plants. ${ }^{54}$

Madre Rosita belonged to a division of the Brigadas Femeninas which carried munitions and equipment to the soldiers in the field. On one occasion she and three other women were travelling from Mexico City to Guadalajara with munitions concealed in chalecos, special vests, under their clothing when police announced a search. Huddling in her seat, Madre Rosita was not discovered, but her three companions were arrested and sent to Islas Marías. 55

Several religious communities which were under the jurisdiction of the bishops were given permission to remain in Mexico. The Sisters of the Servants of the Sacred Heart continued their novitiate in the Cristero stronghold of Zamora, Michoacán, without government opposition. "We knew nothing of what was happening except that the government was persecuting the Church," recalled Madre Espinosa, one of fifteen novices. "We never saw beyond the walls of the convent." ${ }^{6}$ Others were not so fortunate and suffered beatings and even death. In the convent of the Blessed Sacrament in Ejutla, Jalisco, Madre Remedios and her sisters were evacuated by federal soldiers in October of 1927. When two of her sisters attempted to remain with Madre Remedios, who was too ill to be moved, the soldiers beat them until they withdrew. Others tried to hide the Blessed Sacrament, but they too were discovered and beaten before they could consume the hosts. Finally, a more humane soldier intervened and the sisters were able to escape. The next day the two of them returned and moved Madre Remedios to a nearby dirty Indian hut, where she died two days later. Madre Rosa, next in charge, fled with her wards to Autlán, where soldiers attacked them. She and her sisters were taken prisoners. While isolated under house arrest and suffering starvation, Madre Rosa fell ill in mid-March and died on April 3.57

In addition to other dangers and afflictions, the religious who remained in Mexico lived in constant fear of rape. The case of Ester Torres Quesada

\footnotetext{
54 Ibid.

55 José Gutiérrez y Gutiérrez, Recuerdos de la gesta cristera (Guadalajara, 1972-1973), Vol. 3, p. 9.

${ }^{56}$ Interview with Madre Rosanna Rodríguez Espinosa, January 17, 1979. Today Madre Espinosa runs an orphanage for girls in Mexico City.

${ }^{57}$ Cardosa, Los mártires mexicanos, pp. 103, 105-107.
} 
provides a typical example. She entered the convent during the war. After soldiers attacked her convent and raped the sisters, Ester and a friend fled to Cuba, where they were able to continue their religious life in peace..$^{58}$

Another group of sisters, the Capuchins of Tlapán, were destined to play a tragic role in the conflict. In 1923 Archbishop José Mora y del Río founded the community and appointed María Concepción Acevedo y de la Llata as abbess. When most religious were fleeing the country, Madre Conchita (as she was affectionately known) asked permission to remain and to continue observing the religious life. Praising the courage of the sisters, the archbishop granted their wish. During the first year, the sisters lived their rules peacefully and opened their convent to people of all classes who came to hear mass and receive spiritual advice.

On January 2, 1928, shortly after the election of a new municipal president, the police invaded the community, placing the sisters and a priest under arrest. After removing their habits the sisters were ordered to walk to the station nine blocks away. A large crowd gathered outside the convent, hoping to prevent the arrest but to no avail. After a short hearing, the inspector fined the priest $\$ 500.00$ and ordered the sisters to disband. Turned out into the streets in the middle of the night, the Capuchins began their life as hunted criminals, moving from house to house to avoid arrest.

Soon they established themselves in a house, and their friends once again came to hear mass and receive spiritual consolation. "Sometimes agents arrived," recalled Madre Conchita, "but seeing our sincerity, fervor, and humility, they didn't dare turn us in." 59 The Capuchin community lived an austere life, yet it persevered and even flourished amidst the violent persecution. New members arrived, took the habit and made profession as the community grew. The sister occupied themselves with strict observance of the rule and the ordinary household tasks.

In February of 1927 Padre Miguel Agustín Pro visited the convent for the first time, but he made no special impression upon Madre Conchita. "I saw in every priest a potential martyr, and I saw potential martyrs every day," she related. ${ }^{60}$ Several months later, however, their relationship would change dramatically. On that occasion Madre Conchita attended a 1928.

\footnotetext{
${ }^{58}$ A letter from Mercedes Torres Quesada to her cousin, Rafael Ramírez Torres, S. J., March 23

${ }^{59}$ Hoy, August 12, 1944, p. 30 .

${ }^{60}$ Ihid., p. 31 .
} 
spiritual conference given by Father Pro to the women of Colonia Roma. After hearing her confession, Father Pro said to her, "You and I are going to offer ourselves as victims to Divine justice for the salvation of the faith in Mexico and the peace of the Church and the conversion of her persecutors. ${ }^{61}$ Visibly shaken by the message, Madre Conchita agreed to ask permission of her regular confessor before making any such promise. Having obtained this permission, she told her sisters of her intention. They received the news with great enthusiasm and joy, and all prepared for a special mass to be offered by Father Pro, during which he and Madre Conchita would make their offering to God.

From then on Father Pro became a frequent visitor to the Capuchin convent, but he did not have to wait long to fulfill his promise. On November 23, 1927, Father Pro was executed by the government for his alleged participation in the attempted assassination of President Obregón. Disguised as a member of his family, Madre Conchita visited Father Pro the day before he died, but she did not witness his execution. ${ }^{62}$ Father Pro had fulfilled his offering by death, but a different martyrdom awaited Madre Conchita.

One of the most difficult trials Madre Conchita suffered was the suspicion of church authorities. Rumors circulated that the Capuchins were taking communion to prisoners and that suspicious persons were visiting their community. One day Canon Melesio Rodríguez arrived at the convent to investigate these charges. Impressed by the piety and quiet of the community, the canon dropped all charges against the sisters. ${ }^{63}$

A month later, however, new rumors prompted the archbishop to order the community to move immediately to another house or to disband. The sisters, now 22 strong, returned to 60 Zaragoza Street. Denied any outside visitors except the chaplain for the next two and a half months, the sisters enjoyed the solitude of the religious life they had once known. ${ }^{64}$ But this tranquil period was a preparation for more serious difficulties.

The peaceful solitude of the community was interrupted one day when Juan José Toral, with special permission from the archbishop, came to visit Madre Conchita. Madre Conchita had first met this man, destined to play an important role in her life and in the history of Mexico, in March,

${ }^{61}$ Hoy, August 19, 1944, p. 36.

${ }^{62}$ Hoy, August 26, 1944, p. 35.

${ }^{63}$ Hoy. September 9, 1944, pp. 36-38.

${ }^{64}$ Ibid., p. 38. 
1928. An introverted mystic, Toral was deeply troubled over the death of Father Pro and the continued persecution of the Church. He began to visit Madre Conchita often, and she tried to console him and put his mind at rest. They talked for some time about his sufferings and the religious problem. Perhaps this was the occasion when Madre Conchita uttered the damaging statement which would be used against her later: "What I do know is that for the thing to be settled it is indispensable that Obregón, Calles and Patriarch Perez die."6s

A few days later Toral received permission to serve mass at the convent. On the 16th and 17th of July he arrived with the chaplain and left immediately after mass. On the 17 th, news of Obregón's assassination reached the sisters. The following day the chaplain arrived alone, although this was not unusual. Later the same day Dolores, Madre Conchita's sister, brought word that Toral was being held for the assassination. While they were talking, the police arrived with Toral. After thoroughly searching the house, the police arrested the sisters and took them to the station for questioning. "We were taken to the cellar and were given some newspapers to sleep on," Madre Conchita recalled. "We sang and prayed, and then an army of rats invaded us." ${ }^{66}$ Soon Madre Conchita was taken to the jail in San Angel, formerly the convent of Carmen. "And I began my walk on a path that Dante could not imagine," she recalled. ${ }^{67}$ During the next ten months she never undressed and had to sleep reclining on a mat.

Several explanations have been offered in defense of Toral's indiscreet decision to bring the police to Madre Conchita's convent, thus implicating her and her sisters. Leonor Rubio, a mutual friend, wrote a month later that Toral and Madre Conchita had made a pact to offer their lives for Christ the King. ${ }^{68}$ Others thought Toral had come to the convent for advice. Madre Conchita claimed that the police wanted Toral to prove he was a Catholic. After being assured that she would not be implicated, he agreed to take the police to Madre Conchita, who would identify him. Thus the tragic drama unfolded. ${ }^{69}$

On November 2, 1928, at the courthouse in San Ángel, the most sensational Mexican trial of the century began. A large crowd of curious

\footnotetext{
${ }^{65}$ Antonio Rius Facius, Mejico Cristero (Mexico: Editorial Patria, 1966), p. 369.

${ }^{66}$ Hoy, September 24, 1944, p. 36.

67 lbid.

${ }^{68}$ Universidad Nacional Autónoma de Mexico (UNAM), Archivos Historicos Fondo: Liga Nacional Defensora de la Libertad, Miguel Palomar y Vizcarra, Letter of August, 1928.

${ }^{69}$ Interviu, 1979, p. 25. (Xeroxed copy from Madre Conchita without exact date. Magazine was unavailable in the libraries.)
} 
onlookers gathered outside as Madre Conchita was escorted into the courtroom. A woman presented her with a bouquet of flowers while others shouted insults. Demetrio Sodi, president of the Sumpreme Court and minister of justice under Díaz, agreed to take the case after an appeal by Toral's wife. However, the emotional climate of the courtroom made it impossible to conduct a fair trial. The pro-government crowd cheered each time the prosecution spoke and hissed when the defense took the stand. Many persons were indicted simply because they were friends of Toral. Jurors had been paid to convict the defendants and were forced to carry guns into the courtroom to protect their lives. In this hostile atmosphere Sodi attempted to prove that religious persecution had caused the crime, making it a political offense and not punishable by death. The government, which portrayed the defendants as common bandits, declared Madre Conchita the intellectual author of the crime. The result of the week-long trial surprised few. Toral was sentenced to death, while Madre Conchita was given a 20-year prison term, since the law forbade the execution of women. ${ }^{70}$

During the next thirteen years Madre Conchita was moved from one prison to another, sailing three times to Islas Marias, a place reserved for the most hardened criminals. Suffering calumnies, cruelties, and ill health, she sustained herself in desolation through prayer and the encouragement of friends. Facing the prospect of a second trip to Islas Marias in October of 1934, Madre Conchita decided to ask permission to marry Carlos Balda, a friend and frequent visitor of her convent. ${ }^{71}$ Since she would be the only woman prisoner of Islas Marias, the archbishop supported her decision to marry. Pius XI, who had released her community from vows on July 18, 1928, also sent his blessing and conferred upon her all the prerogatives of a religious. Years later Madre Conchita reflected, "I accepted matrimony hoping he [Carlos] would inject his ardent faith into me, for mine was almost dead... The decision was not made without doubts or anxiety, but now I know it was right." 72

One of the first acts of the new president, Manuel Ávila Camacho, was to release Madre Conchita from prison on December 9, 1940. She and her husband moved to a small apartment on Obregón Street in Mexico City, where they lived modestly by making sandals. Out of financial necessity Madre Conchita published her memoirs in Hoy in 1944 and later wrote a

\footnotetext{
${ }^{70}$ John W. F. Dulles, Yesterday in Mexico (Austin: University of Texas Press, 1961), pp. 399-401.

${ }^{71}$ Carlos Balda was imprisoned for his part in the bombing of the senate chambers in 1928.

72 María Concepción Acevedo y de la Llata, Una mártir de México (Madrid: "Gráfica Marsiega, 1965), pp. 394, 401 .
} 
more comprehensive account in Una mártir de México. These endeavors and the contributions of friends helped sustain the couple in a simple life style until Madre Conchita's death on August 30, 1979. ${ }^{73}$

The former Capuchin nun had suffered not only at the hands of the government but also through attacks of Catholics supporting the Cristero cause. Archbishop de la Mora publicly referred to mental abnormalities in her and her family. ${ }^{74}$ Sofia del Valle admitted, "She was, I think, a good nun, but there was something not normal about her." Sofía was referring to an incident at the convent at Tlapán. After ignoring several invitations from Madre Conchita, Sofia reluctantly agreed to see her. While they visited the chapel, Madre Conchita pointed out two wax figures, a 'tarantula and a scorpion, on either side of the tabernacle. She claimed that they represented Obregón and Calles, who would kill you if you didn't kill them. Disapproving of such a display, Sofía answered, "They are souls and this is not my way of prayer." 75 Greatly disturbed by this incident, Sofia vowed never to return.

Even though some question Madre Conchita's judgment or criticize her involvement in the political affairs of that time, most people today speak of her with affection and admiration. Sra. Dolores Ortega recalled, "She is a highly virtuous woman... to me a truthful woman, a saint." 76 General Eulogio Salazar Villegas, who was ordered to take Madre Conchita to Islas Marías, insisted, "She was innocent. She was a generous woman, noble, profoundly Christian, self-sacrificing, and human." 17 José Gutiérrez lamented, "What a pity that Madre Conchita was a victim!"78 Emerging from her ordeal without bitterness or hatred, Madre Conchita evoked the admiration of most who knew her. She ended her days in peace and contentment, convinced she had faithfully carried out the will of God. ${ }^{79}$

${ }^{73}$ Excélsior, August 31, 1979; September 1, 1979. Madre Conchita died at the age of 87. Thousands viewed her remains. A group of about fifty close friends accompanied her body to the cemetary and broke out into the Cristero hymn at the grave site. Her husband, Carlos Balda, maintained her innocence until the end, saying. "The whole world knows [of her innocence] and the people have absolved her."

${ }^{74}$ Dulles, Yesterday, p. 398.

75 Interview with Sofia del Valle, January 19, 1979

${ }^{76}$ Taped interview with Dolores Ortega de Diaz de Sollano, September 3, 1978.

77 Archivo de la Palabra, Museo Nacional de Antropología (México, D. F.) PH 0-1-37.

78 Interview with José Gutiérrez, February 8, 1979.

${ }^{79}$ Interview with María Concepción Acevedo y de la Llata (Madre Conchita) and Carlos Balda, March 5, 1979. Carlos Balda permitted the interview under the conditions that I use no tape recorder and limit my questions to Madre Conchita, who was tired and "emotional" after Pope John Paul II's visit to Mexico. The walls of the apartment were covered with holy pictures and a picture of the Pope, Juan Toral, Father Pro, and other Cristeros. While I was there, a steady stream of visitors passed through the small room. 
While Madre Conchita's case was the most spectacular, she was but one among hundreds of religious women who received permission to remain in the country in spite of the threat of arrest and imprisonment, thereby rendering significant service to the Cristero cause. Converting their homes or temporary refuges into chapels, they provided for the spiritual needs of all Catholics, from the poorest farmer to the chief of the army. A source of inspiration and hope to the men and women in the field, they helped make viable a cause that many had assumed to be hopeless.

Although las señoras and las religiosas played an essential role in the Cristero rebellion, this role was generally one of passive resistance. Nevertheless, whether as passive resisters or active participants, these women had responded to a crisis in Mexico as women had in the past; and when the war ended in 1929, once again they returned to their families or to works which were the extension of the family-health, education, and welfare.

Ironically, the church, the very institution which sanctified the role of women as custodians of the family's morals, gave women the opportunity to move out of their sphere of influence into the "male" world of violent confrontation. As women opposed the government, the church looked the other way and in some cases openly supported the women's endeavors. The question of religious freedom provided women with perhaps the only issue which could have mobilized all classes to join the resistance movement. And Christian women were well prepared for work which required the virtues of self-sacrifice, abnegation, and forbearance. In addition, the church had encouraged higher education for women and had given them administrative experience in church-sponsored organizations. They used these skills to build an intelligence network, to organize a propaganda system, and to form a women's army.

But if it was the church that provided women with the motivation and experience to help organize the resistance against the government, it was, nevertheless, the same church which compelled them to return to their "proper" role once the crisis had passed. The church's stand on the place of women in society could not have been stated more clearly than in an address by Refugio Goribar de Cortina, one year after the war. A former leader of the Damas, Cortina had been an active propagandist during the rebellion. Speaking to the apostolic delegate and the directors of Catholic Action, Cortina informed them that women would continue teaching catechism, consoling the sick, and visiting hospitals. However, in response to a recent appeal by Pius XI, a new emphasis would be placed on strengthening the Christian family. She declared, "The family is our 
kingdom, and only in it will we truly reign. It is our camp. All other work of women is useless." ${ }^{80}$ In the conclusion of her talk Cortina reminded her audience of the unconditional obedience women gave to Rome and the bishops at the end of the rebellion, and she assured them that they would continue to follow the prelates' counsel. Undoubtedly Pius XI was aware of the changing role of women throughout the world and might have feared the weakening of the family as women moved outside the home. Universally, a break was beginning to appear in the traditional structure, and Mexico was, after all, a part of the universe.

Seton Hill College

Greensburg, Pennsylvania

Sr. Barbara Miller

${ }^{80}$ Rius Facius Archives. The address was delivered June 29, 1930, from the former Social Secretariat Center on 9 Motolinia Street. 